\title{
Humor in the Classroom: Learning Through Laughter
}

Chrissy Whiting-Madison", Kevin M.P. Woller

Department of Psychology and Sociology, Rogers State University, Claremore, Oklahoma, United States.

\author{
Article Details \\ Article Type: Research Article \\ Received date: $07^{\text {th }}$ December, 2020 \\ Accepted date: $12^{\text {th }}$ January, 2021 \\ Published date: $14^{\text {th }}$ January, 2021
}

"Corresponding Author: Chrissy Whiting-Madison, Department of Psychology and Sociology, Rogers State University, Claremore, Oklahoma, United States. E-mail: cwhiting@rsu.edu

Citation: Whiting-Madison, C. \& Woller, K.M.P. (2021). Humor in the Classroom: Learning Through Laughter. J Ment Health Soc Behav 3(1):127. https://doi.org/10.33790/jmhsb1100127

Copyright: $\mathbb{C} 2021$, This is an open-access article distributed under the terms of the Creative Commons Attribution License 4.0, which permits unrestricted use, distribution, and reproduction in any medium, provided the original author and source are credited.

\section{Abstract}

Although the appropriateness of humor in the college classroom has been debated for much of the 20th century, little research exists as to what benefit humor actually plays in the context of a college classroom. To address these gaps in literature, 13 students were selected at random from a regional institution in Northeastern Oklahoma to be interviewed at depth regarding professors' use of humor in the college classroom. The research team found that the use of humor in the college classroom can lighten mood, provide a welcome space for a mental break, promote social cohesion, and serve to increase the retention of information.

\section{Introduction}

The appropriateness of humor in the classroom has been debated among researchers and educators alike for the majority of the 20th century [1]. Research has discussed the potential of laughter in the curriculum, specifically if it possesses the ability to promote or hinder the learning process [2]. Much research proposes that humor does indeed enhance the learning experience [3]. While perhaps not affecting learning directly, it promotes cohesion and community among students and instructor while also diminishing conflict. It also makes students feel more comfortable, thus making them more receptive to instruction [1].

However, one cannot immediately jump to the conclusion that all instructors also need to simultaneously embrace their inner comics. Other studiesput forward that the type of humor matters in regard to establishing this rapport among faculty and learners $[1,4,5]$. One such study suggested that the use of appropriate, instructional humor did promote learning. However, the use of disparaging and offensive humor did just the opposite, failing to promote learning in the classroom, and ultimately resulting in derision [2]. Another potential hindrance to the use of humor in the classroom is the generational differences in what is considered funny. In other words, the humor of the older professor is ultimately lost on the younger student [6].

These, however, are not the only potential downsides to humor in the classroom. Another possible issue exists when the humor is simply not understood, for reasons beyond generational differences. Students who don't find a professor's particular brand of humor to be entertaining has a greater likelihood of not paying attention or gaining the knowledge necessary for completion of the course. This often happens when a joke is aimed towards a student with a certain level of competency that has yet to be reached by the current class. For example, a higher level chemistry joke, may be completely over the head of the usual Introduction to Chemistry student.

Other students are often offended by humor in the classroom. This is most common when a professor is rude, deprecating to other students or simply trying too hard to be funny [7].

Garner [7] does go on to point out that important lessons exist here in regard to humor in the classroom. Teachers should be cognizant of their own humor. For example, are the students laughing? Selfawareness is key. Teachers should be careful to avoid embarrassing humor or humor that goes over the head of their students for any reason. Inappropriate humor serves to be a distraction and a hindrance to the learning process, and students report feeling like their time was wasted, rather than utilized appropriately [8-12].

Research does seem to suggest that humor carries more benefits than detriments in regards to learning. Not only does it promote a sense of community, but it also allows for a plethora of health benefits including reduced anxiety $[6,13,14]$, improved respiration and circulation $[6,7]$, and also can reduce stress and increase mental acuity $[6,15]$.

From a biological standpoint, humor can even activate parts of your brain that are otherwise not utilized within the confines of a classroom. In one particular study, researcher and educator, Mary Kay Morrison, utilized brain scans to determine if brain activity was affected when humor was infused into the classroom curriculum. Not only did she find increased activity, she found it in multiple areas of the brain. She concluded that this increased activity not only maximized learning potential, but also strengthened memories [16].

Additional research suggests that humor builds confidence in the self-esteem lacking student, while simultaneously alleviating the common classroom problems of anxiety and boredom. This study went to far as to encourage educators to plan humor, by intentionally infusing it into your classroom curriculum, suggesting that the intention was just as important as the actual humor [17].

As Garner [7] astutely — and humorously — observed, "When properly used, humor can be an effective tool to make a class more enjoyable, reduce anxiety and improve the learning setting. The 'ha ha' of humor in the classroom may indeed contribute to the 'aha' of learning from the student."

In this manuscript, we set out to explore the use of humor in the college classroom. Specifically does the use of a professor's humor in the college classroom foster learning or detract from it?

\section{Methods and Results}

No previously designed survey existed to explore the use of professors' humor in college classrooms. Therefore, the research team designed a survey based on the research question and prior literature on the subject. Three additional researchers reviewed the survey and evaluated the appropriateness of each survey question. 
Does the use of a professor's humor in the college classroom foster learning or detract from it?

\begin{tabular}{|c|c|c|}
\hline & & Students $(\mathrm{N}=13)$ \\
\hline \multirow[t]{2}{*}{ Gender } & Female & 8 \\
\hline & Male & 5 \\
\hline \multirow[t]{4}{*}{ Race/Ethnicity } & White/Caucasian & 8 \\
\hline & Native American & 2 \\
\hline & Hispanic/Latino & 2 \\
\hline & Other & 1 \\
\hline \multirow[t]{4}{*}{ Age } & $18-22$ & 11 \\
\hline & $23-27$ & 0 \\
\hline & $28-32$ & 0 \\
\hline & $33+$ & 2 \\
\hline \multirow[t]{4}{*}{ Student Status } & Freshman & 1 \\
\hline & Sophomore & 3 \\
\hline & Junior & 2 \\
\hline & Senior & 5 \\
\hline \multirow[t]{7}{*}{ Major } & Psychology & 3 \\
\hline & Nursing & 3 \\
\hline & Community Counseling & 3 \\
\hline & Social Science & 1 \\
\hline & Sociology & 1 \\
\hline & Cybersecurity & 1 \\
\hline & Accounting & 1 \\
\hline
\end{tabular}

Students reported that the use of humor is beneficial in the college classroom, particularly when is humor that is not perceived as aggressive or politically insensitive. Students agreed that when utilized appropriately, humor in the college classroom can lighten the mood of the class, provide a welcome space for a mental break, promote social cohesion, and serve to increase retention of information.

\begin{tabular}{|c|c|c|c|}
\hline Theme & Description of Theme & Example Student Quote & Example Student Quote \\
\hline Humor lightens mood & $\begin{array}{l}\text { Makes students feel more } \\
\text { comfortable }\end{array}$ & $\begin{array}{l}\text { "It keeps you thinking and } \\
\text { it makes lecture a lot less } \\
\text { dull" }\end{array}$ & $\begin{array}{l}\text { "When there is humor it } \\
\text { just makes the class more } \\
\text { enjoyable to be in" }\end{array}$ \\
\hline $\begin{array}{l}\text { Provides a welcome space } \\
\text { for a mental break }\end{array}$ & $\begin{array}{l}\text { Enlivens dry content and } \\
\text { decreases stress levels in } \\
\text { difficult classes }\end{array}$ & $\begin{array}{l}\text { "There are some subjects } \\
\text { that need to be kept more } \\
\text { light-hearted" }\end{array}$ & $\begin{array}{l}\text { "It doesn't feel like a } \\
\text { lecture, it feels like they are } \\
\text { having a conversation with } \\
\text { me." }\end{array}$ \\
\hline Promotes social cohesion & $\begin{array}{l}\text { Professor humor may } \\
\text { represent socially } \\
\text { supportive instructor, one } \\
\text { who thinks teaching is } \\
\text { more than just a job }\end{array}$ & $\begin{array}{l}\text { "I believe it does support } \\
\text { community and help with } \\
\text { learning." }\end{array}$ & $\begin{array}{l}\text { "If someone is cracking a } \\
\text { joke it just relaxes everyone } \\
\text { and allows everybody to } \\
\text { come out of their shell a } \\
\text { little bit and talk more." }\end{array}$ \\
\hline $\begin{array}{l}\text { Serve to increase retention } \\
\text { of information }\end{array}$ & $\begin{array}{l}\text { Funny mnemonic devices, } \\
\text { jokes related to class } \\
\text { content, puns }\end{array}$ & $\begin{array}{l}\text { "Humor helps me } \\
\text { remember things and keeps } \\
\text { me more on the ball" }\end{array}$ & $\begin{array}{l}\text { "If they make a funny thing } \\
\text { or say a funny thing for you } \\
\text { to remember something, } \\
\text { like we'll remember it } \\
\text { because she made this } \\
\text { joke." }\end{array}$ \\
\hline
\end{tabular}

Table 2: Students' Reasons as to Why They Appreciate Humor in the College Classroom 


\section{Conclusions}

The majority of participants in this study appear to appreciate when instructors use humor in college classrooms. They enjoyed the lightened mood, particularly regarding lecture containing sensitive subject matter. The students also enjoyed the cohesion that humor brought to the classroom experience. While professor humor tended to positively affect classroom mood, this was only when humor used was deemed "appropriate" rather than "politically incorrect," "sarcastic, or distracting.

The majority of students interviewed also stated that humor provided a space for mental breaks, again particularly when subject matter was considered sensitive or serious. These mental breaks provided students with an opportunity to bond with classmates and instructor alike and also seemed to make the professor more supportive.

Classroom humor also seemed to assist with retention of information, it was also stated that some "inappropriate" humor may be considered an unwelcome intrusion. Specifically when the humor was interpreted as politically incorrect, sarcastic, or distracting. Otherwise, it actually helped the students to learn and remember the information presented in classroom lecture.

\section{Limitations}

This research was conducted through the recruitment across multiple classes at one school in Northeastern Oklahoma. Since, sense of humor and what is considered funny can be highly dependent on culture, these finding may not be applicable in other countries, states or even regions. This research was solely dependent on student's perceptions of the humor utilized by their professors within the context of the college classroom, which could be influenced by other variables including past experiences with the professor and specifically, past experiences with that particular professor's sense of humor. Therefore, generalizations from this study should only be made with caution.

Conflicts of interest/Competing interests: I have no known conflicts of interest to disclose.

1. Martin, R. A., Puhlik-Doris, P., Larsen, G., Gray, J., \& Weir, K. (2003). Individual differences in uses of humor and their relation to psychological well-being: Development of the humor styles questionnaire. Journal of Research in Personality, 37(1), 48-75. doi:10.1016/S0092-6566(02)00534-2

2. Wanzer, M. B., Frymier, A. B., \& Irwin, J. (2010). An explanation of the relationship between instructor humor and student learning: Instructional humor processing theory. Communication Education, 59(1), 1-18. doi:10.1080/03634520903367238.

3. Lei, S. A., Cohen, J. L., \&Russler, K. M. (2010). Humor on Learning in the College Classroom: Evaluating Benefits and Drawbacks From Instructors' Perspectives. Journal of Instructional Psychology, 37(4), 326-331.

4. Imlawi, J., \& Gregg, D. (2014). Engagement in online social networks: The impact of self-disclosure and humor. International Journal of Human-Computer Interaction, 30(2), 106-125. doi:10.1080/10447318.2013.839901

5. Goodboy, A. K., Booth-Butterfield, M., Bolkan, S., \& Griffin, D. J. (2015). The role of instructor humor and students' educational orientations inStudent learning, extra effort, participation, and out-of-class communication. Communication Quarterly, 63(1), 44-61. doi:10.1080/01463373.2014.965840.

6. Seidman, A. (2016). I'm not joking. but maybe I should start? Reading Improvement, 53(1),

7. Garner, R. L. (2006). Humor in pedagogy: How ha-ha can lead to aha. College Teaching, 54(1), 177-180. doi:10.3200/ CTCH.54.1.177-180
1. Banas, J.A., Dunbar, N., Rodriguez, D., and Liu, S. (2011). A review of humor in education settings: Four decades of research. Communication Education, 60(1), 115-144.

2. Buskist, W., Sikorski, J., Buckley, T., \& Saville, B.K. (2002). Elements of master teaching. In S.F. Davis, \& W. Buskist (Eds.). The teaching of psychology: Essays in honor of Wilbert $J$. McKeachie and Charles L. Brewer (27-39).

3. Busler, J., Kirk, C. Keeley, \& Buskist, W. (2017). What constitutes poor teaching? A preliminary inquiry into the misbehaviors of not-so-good instructors. Teaching of Psychology, 44(4), 330344. doi: 10.1177/0098628317727907.

4. Huss, J. \& Eastep, S. (2016). The attitudes of university faculty toward humor as a pedagogical tool: Can we take a joke? Journal of Inquiry \& Action in Education, 8(1), 39-65.

5. Kruger, J., \& Dunning, D. (1999). Unskilled and unaware of it: How difficulties in recognizing one's own incompetence lead to inflated self-assessments. Journal of Personality and Social Psychology, 77(6), 1121-1134.

6. Shibinski, K., \& Martin, M. (2010). The role of humor in enhancing the classroom climate. Athletic Therapy Today, 15(5), 27-29. doi:10.1123/att.15.5.27.

7. Lems, K. (2011). Pun work helps English learners get the joke. The Reading Teacher, 65(3), 197-202. doi:10.1002/TRTR.01027

8. Berk, R. (1998). Professors are from Mars, students are from Snickers. Madison, WI. Mendota

9. Morrison, M. K. (2008;2010;). Using humor to maximize learning: The links between positive emotions and education. US: R\&L Education.

10. Celik, M. (2004). Humor: What can it do for tertiary students? Hacettepe University Journal of Education, 27, 59. 